\title{
Studies on the growth and changes in metabolism of rats fed on carbohydrate-deficient fatty acid- based diets supplemented with graded levels of maize starch*
}

\author{
By S. S. AKRABAWI, MERRY M. SAEgERT and J. P. SALJI \\ Department of Food Technology and Nutrition, American University of Beirut, \\ Beirut, Lebanon
}

(Received I8 Fuly 1973 - Accepted I March 1974)

\begin{abstract}
1. Experiments were conducted to determine the effects of the supplementation of carbohydrate-deficient fatty acid-based (FA) diets with $18.7,37.5,75,150$ and 300 g maize starch (MS) $/ \mathrm{kg}$ on the growth and metabolism of the growing rat. Further, the effects of fasting on rats given the FA diet were compared with those given the high-carbohydrate (CHO) diet. Due to the significant decrease in food consumption of rats given the FA diet, the effects of pair-feeding the $\mathrm{CHO}$ and the FA diet were also investigated.

2. The isoenergetic replacement of fatty acids with increasing amounts of MS in the FA diet given to rats increased their weight gain and concentration of glucose in their plasma. These increases, however, tended to level off for weight gain and glucose concentration, respectively, at about $18.7 \mathrm{~g}$ and $75 \mathrm{~g} \mathrm{MS} / \mathrm{kg}$ diet. The same type of replacement decreased the concentration of ketones in the plasma but the decrease levelled off at the high concentration of $300 \mathrm{~g} \mathrm{MS} / \mathrm{kg}$ diet. Activities of liver glucose-6-phosphatase (EC 3.1.3.9) and glucokinase $(E C 2.7 .1 .2)$ decreased and increased respectively with increasing concentration of maize starch in the diet. These changes tended to level off at concentrations of about $75^{-150} \mathrm{~g}$ $\mathrm{MS} / \mathrm{kg}$ diet.

3. Fasting for $18 \mathrm{~h}$ decreased the concentration of glucose in plasma of both the FA- and the $\mathrm{CHO}$-fed rats, while fasting of the CHO-fed rats depressed the concentration of glycogen in the liver but did not influence that of the FA-fed rats. Pair-feeding the CHO diet to the FA diet produced similar weight increases during the 8-week experimental period.
\end{abstract}

The consequences of the removal of carbohydrate from the diet on growth and metabolic rate have been given little scientific attention until recently. This is probably because of the abundant supply of carbohydrate in the diet. The importance of carbohydrate, however, has long been known. The interconversion of carbohydrate and protein and the ability of dietary carbohydrate to spare protein was reported early in this century by Lusk (1923).

Recent studies have questioned the exact role and need for carbohydrate in the diet. Renner \& Elcombe (1964) established the need for a small quantity of carbohydrate in the form of glucose or glycerol to prevent growth retardation of chicks fed on a diet in which the non-protein energy was derived from a mixture of fatty acids (FA). Brambila \& Hill (1966, I 967) confirmed these findings and observed that graded supplementation with glucose of a FA diet containing $310 \mathrm{~g}$ soya-bean protein $/ \mathrm{kg}$ progressively improved growth. It was necessary, however, to reach a level of $45 \%$ of the energy from glucose before growth rates approached those of the high-carbohydrate diet (CHO).

* Contribution of the Faculty of Agricultural Sciences of the American University of Beirut, Beirut, Lebanon as journal No. 4I4. 
Some aspects of the metabolism of rats given the FA diet and the effects of feeding such a diet in a single daily meal were published by Akrabawi \& Hill (1970), Goldberg (I97I) and Akrabawi \& Salji (1973). The results of these studies, as well as those of Allred (I969) and Allred \& Roehrig (1970), showed that rats as well as chicks given the FA diet had low concentrations of glucose and high concentrations of ketones in the blood and a reduced concentration of glycogen in the liver, while the activities of liver glucokinase (GK) $(E C$ 2.7.1.2) and glucose-6-phosphatase (G-6-Pase) $(E C 3.1 .3 .9)$ decreased and increased respectively. These changes in liver metabolites and enzymes would allow a net synthesis of glucose and are similar to results normally encountered when animals receiving a high-carbohydrate diet are fasted.

The present study represents an effort to determine the minimum amount of maize starch (MS) that is needed to abolish the growth and metabolic consequences of the dependence, due to the ingestion of the FA diet, on gluconeogenesis for the supply of carbohydrate to the tissues. Because rats fed on the FA diet exhibit metabolic changes that are characteristic of the fasting condition when a high-carbohydrate diet is given, the effects of fasting on the concentration of glucose and ketone bodies in plasma and the concentration of liver glycogen were studied in rats receiving the FA diet. Further, since giving the FA diet always results in a significant drop in food consumption concomitant with the reduction of weight decrease, the question has been raised, whether this decrease in weight gain was due to the ingestion of the FA diet or depression in food intake. In an attempt to answer this question, which is a recurring one in all instances where a nutrient deficiency produces a proportional drop in food intake, the growth of rats fed on the FA diet were compared with that of rats pair-fed on the $\mathrm{CHO}$ diet during an 8-week experimental period.

\section{EXPERIMENTAL}

\section{Animals and diets}

The source of the experimental animals, their pre-experimental treatments and the housing conditions have been previously described (Akrabawi \& Salji, I973). The composition of the experimental diets is shown in Table I. The carbohydrate-deficient fatty acid-based diet (FA) contained no energy from carbohydrate while the carbohydrate diet (CHO) contained $583 \mathrm{~g}$ carbohydrate $/ \mathrm{kg}$ in the form of MS. All diets were isonitrogenous and the ratio, protein:non-protein energy was kept constant by adjusting the cellulose content of the diets. All diets were given ad lib. except when the effects of fasting and pair-feeding were tested. Throughout the experiment in which the effect of fasting was tested, food was placed in the animal cages daily at 08.30 hours and the rats were allowed to eat until 20.30 hours, at which time the food was removed. On the last day of the experiment, half the rats were given their food at the regular time, but were killed by chloroform anaesthesia at I I.30 hours, and blood and liver samples were collected. The results obtained at that time represented the fed state. The other half were kept without food until 14.30 hours, when they were also killed, and samples were collected to represent the fasted state. 
Table I. Composition ( $g / k g$ dry matter) of the fatty acid $(F A), F A$ supplemented with graded levels of maize starch $(M S)$ and carbohydrate $(C H O)$ diets given to rats

$\quad$ Ingredient
Casein*
Cellulose $\nmid$
Mineral mixture $\$$
Vitamin mixture
Maize starch
Fatty acids§
Maize oil

$F A$
217
338
60
20
0
365
0

FA supplemented with MS ( $\mathrm{g} / \mathrm{kg}$ dry matter)

$\begin{array}{lcrrrr}18.7 & 37.5 & 75 & \text { 150 } & 300 & \text { CHO } \\ 217 & 217 & 217 & 217 & 217 & 217 \\ 327.3 & 316.5 & 296 & 255 & 171 & 20 \\ 60 & 60 & 60 & 60 & 60 & 60 \\ 20 & 20 & 20 & 20 & 20 & 20 \\ 18.7 & 37.5 & 75 & 150 & 300 & 583 \\ 357 & 349 & 332 & 298 & 232 & 0 \\ 0 & 0 & 0 & 0 & 0 & 100\end{array}$

* Vitamin-free.

† Alphacel; Nutritional Biochemical Corporation, Cleveland, Ohio, USA.

$\ddagger$ For composition, see Akrabawi \& Salji (1973).

$\S$ A mixture of fatty acids from maize oil and olive oil $(50: 50, w / w)$.

\section{Analytical methods}

The concentrations of glucose and total ketone bodies in plasma and the concentration of liver glycogen were determined according to methods described previously by Akrabawi \& Salji (1973). The activity of G-6-Pase was assayed according to the method described by Harper (1965). The activity of GK was assayed with some modifications according to a method described by several authors (DiPietro, Sharma \& Weinhouse, I962; Walker, 1963 ; Wood, I966). I $g$ liver from a rat that had been bled by cardiac puncture was homogenized in $4 \mathrm{ml}$ ice-cold homogenizing medium $\left(\mathrm{pH} 7.0\right.$ ) composed of $0.15 \mathrm{M}-\mathrm{KCl}, 0.004 \mathrm{M}^{-\mathrm{MgSO}_{4}}$ and $0.004 \mathrm{M}$-ethylenediaminetetraacetic acid. The homogenate was centrifuged at $4^{\circ}$ for $20 \mathrm{~min}$ at $12 \mathrm{I} 00 \mathrm{~g}$. The supernatant was then assayed for GK activity by measuring, with a recording spectrophotometer, the increase in extinction at $340 \mathrm{~nm}$ as a measure of the production of reduced NADP. Into each of the cuvettes used for the assay the following were added: $0.6 \mathrm{ml} 0.25 \mathrm{M}$-glycylglycine buffer $\left(\mathrm{pH} 7.5\right.$ ), $0.3 \mathrm{ml} 0.075 \mathrm{M}-\mathrm{MgSO}_{4}, 0.2 \mathrm{ml}$ $7.5 \mathrm{~mm}-\mathrm{NADP}^{+}, 0.3 \mathrm{ml} \mathrm{G}-6-\mathrm{P}$ dehydrogenase solution (4 units $/ \mathrm{ml}$ ) and $0.4 \mathrm{ml}$ $0.75 \mathrm{M}$-D-glucose. To start the reaction, $\mathrm{O} . \mathrm{I} \mathrm{ml}$ homogenate supernatant and $0.2 \mathrm{ml}$ $0.075 \mathrm{M}$-ATP were added to the assay cuvette while $0.1 \mathrm{ml}$ homogenate supernatant and $0.2 \mathrm{ml}$ buffer were added to the reference cuvette. All chemicals were obtained from Sigma Chemical Co., St Louis, Missouri, USA. Solutions were made in $0.25 \mathrm{M}$-glycylglycine buffer.

Results from all experiments were transformed into logarithms and analysed statistically by analysis of variance (Snedecor, 1957). Differences among mean logarithmic values were assessed for all experiments at the $5 \%$ level of probability by the Duncan Multiple Range procedure.

\section{RESULTS}

Results of mean weight increase, food consumption, concentrations of glucose and total ketone bodies in plasma, concentrations of liver glycogen and activities of liver G-6-Pase and GK for rats fed on the FA, FA with 75, 150 and $300 \mathrm{~g} \mathrm{MS} / \mathrm{kg}$, 
Table 2. Mean logarithm and mean values for weight increase, food consumption, concentrations of glucose and total ketone bodies in plasma, concentration of liver glycogen and activities of liver glucose-6-phosphatase (G-6-Pase) and glucokinase $(G K)$ of rats given the fatty acid $(F A), F A+75 g$ maize starch $(M S), F A+15 \circ g M S, F A+300 g$ $M S$ and the carbohydrate (CHO) diets.

(Mean logarithms with their standard errors and mean values (in parentheses) for groups of six rats; experimental period of $17 \mathrm{~d}$ )

\begin{tabular}{|c|c|c|c|c|c|c|}
\hline \multirow[b]{2}{*}{ Diet $\ldots$} & \multirow[b]{2}{*}{ FA } & \multicolumn{3}{|c|}{$\begin{array}{l}\text { FA supplemented with MS } \\
\text { (g/kg dry matter) }\end{array}$} & \multirow[b]{2}{*}{$\mathrm{CHO}$} & \multirow[b]{2}{*}{ SE } \\
\hline & & 75 & 150 & 300 & & \\
\hline Weight increase* $(\mathrm{g})$ & $\begin{array}{l}\text { I. } 4 \text { I I } 2^{a} \\
(40)\end{array}$ & $\begin{array}{l}\mathrm{I} \cdot 88_{3} 6^{b} \\
(77)\end{array}$ & $\begin{array}{l}I \cdot 8870^{b} \\
(80)\end{array}$ & $\begin{array}{l}I^{\cdot} \cdot 946 I^{b} \\
(88)\end{array}$ & $\begin{array}{l}I \cdot 9366^{b} \\
(87)\end{array}$ & 0.1033 \\
\hline Food consumed $(\mathrm{g})$ & $\begin{array}{l}2 \cdot 1776^{a} \\
\left(\mathrm{r}_{50}\right)\end{array}$ & $\begin{array}{l}2 \cdot 3283^{b} \\
(214)\end{array}$ & $\begin{array}{l}2 \cdot 3109^{b} \\
(206)\end{array}$ & $\begin{array}{c}2 \cdot 3467^{b} \\
(224)\end{array}$ & $\begin{array}{l}2 \cdot 3^{102^{b}} \\
(206)\end{array}$ & 0.0289 \\
\hline Plasma glucose $(\mathrm{g} / \mathrm{l})$ & $\begin{array}{r}-0.9667^{a} \\
(0.96)\end{array}$ & $\begin{array}{c}0.0829^{b} \\
(I \cdot 22)\end{array}$ & $\begin{array}{c}0.1252^{b} \\
(1 \cdot 34)\end{array}$ & $\begin{array}{c}0.1247^{b} \\
(\mathrm{I} \cdot 34)\end{array}$ & $\begin{array}{c}0.1599^{b} \\
(I \cdot 45)\end{array}$ & 0.0293 \\
\hline Plasma ketones (mg/l) & $\begin{array}{l}\mathrm{I} \cdot \mathrm{r} 083^{c} \\
(\mathrm{I} 4 \mathrm{I})\end{array}$ & $\begin{array}{l}0.8908^{b} \\
(80)\end{array}$ & $\begin{array}{l}0.7480^{a b} \\
(57)\end{array}$ & $\begin{array}{l}0.6428^{a} \\
(45)\end{array}$ & $\begin{array}{l}0.6151^{a} \\
(43)\end{array}$ & 0.0549 \\
\hline Liver glycogen $(\mathrm{mg} / \mathrm{g})$ & $\begin{array}{l}0 \cdot 2763^{a} \\
(19 \cdot 4)\end{array}$ & $\begin{array}{c}0 \cdot 5476^{b} \\
\left(35^{\circ} 5\right)\end{array}$ & $\begin{array}{c}0.6300^{b c} \\
(43 \cdot 7)\end{array}$ & $\begin{array}{c}0.7285^{c d} \\
(53.9)\end{array}$ & $\begin{array}{c}0 \cdot 83_{3} 68^{d} \\
(70 \cdot 0)\end{array}$ & 0.0378 \\
\hline $\begin{array}{l}\text { G-6-Pase ( } \mu \mathrm{mol} \text { phosphate } \\
\text { released/g per min) }\end{array}$ & $\begin{array}{r}1 \cdot 1262^{b c} \\
(13 \cdot 59)\end{array}$ & $\begin{array}{l}I \cdot 143^{c} \\
(14.07)\end{array}$ & $\begin{array}{l}\mathrm{I} \cdot 06 \mathrm{I}^{a b c} \\
(\mathrm{II} \cdot 98)\end{array}$ & $\begin{array}{r}0.9673^{a} \\
(9.40)\end{array}$ & $\begin{array}{r}\mathbf{I} \cdot 036 \mathbf{2}^{a b} \\
(\mathbf{I} 0 \cdot 90)\end{array}$ & 0.0331 \\
\hline $\begin{array}{l}\mathrm{GK}(\mu \mathrm{mol} \text { NADPH } \\
\text { produced/g per min) }\end{array}$ & $\begin{array}{r}-0.2568^{a} \\
(0.56)\end{array}$ & $\begin{array}{c}0.0080^{b} \\
(\mathrm{I} \cdot 03)\end{array}$ & $\begin{array}{c}0.2094^{c} \\
(\mathrm{I} \cdot 64)\end{array}$ & $\begin{array}{r}0.2218^{c} \\
(I-68)\end{array}$ & $\begin{array}{l}0.1843^{c} \\
(1 \cdot 57)\end{array}$ & 0.0339 \\
\hline
\end{tabular}

and the $\mathrm{CHO}$ diets are presented in Table 2. In comparison with the results obtained with the CHO diet, giving the FA diet depressed weight gain, food consumption, and concentrations of plasma glucose and liver glycogen significantly. Moreover, the FA diet significantly increased the concentration of ketone bodies in the plasma. The inclusion of $75 \mathrm{~g} \mathrm{MS} / \mathrm{kg}$ in the FA diet (Table 2) produced weight gains and concentrations of glucose in the plasma that were not significantly different from those of the rats given the $\mathrm{CHO}$ diet. A larger amount of MS ( $300 \mathrm{~g})$ was required to produce a concentration of ketones in the plasma that was similar to that of rats given the $\mathrm{CHO}$ diet. The concentrations of liver glycogen were progressively increased with larger inclusions of MS in the FA diet. Activities of G-6-Pase and GK decreased and increased respectively with increases in the level of MS in the diet but these changes tended to plateau above the $150 \mathrm{~g} \mathrm{MS} / \mathrm{kg}$ level.

Results obtained from testing the effects of the inclusion in the FA diet of quantities of MS ( 18.7 and $37.5 \mathrm{~g} / \mathrm{kg}$ ) that were less than the $75 \mathrm{~g} / \mathrm{kg}$ already tested are shown in Table 3. Although weight responses within this experiment were similar in their trends to those outlined in Table 2, the weight gains reported in Table 3 were much smaller than those in Table 2. The experiment was carried out in the winter, and it is thought that this may have affected the weight gains for the dietary treatments. The inclusion of $18.7 \mathrm{~g} \mathrm{MS} / \mathrm{kg}$ in the FA diet supported a weight gain that was signifi- 
Table 3. Mean logarithm and mean values for weight increase, food consumption, concentrations of glucose and total ketone bodies in plasma, concentration of liver glycogen and activities of liver glucose-6-phosphatase (G-6-Pase) and glucokinase $(G K)$ of rats given the fatty acid $(F A), F A+18 \cdot 7 g$ maize starch $(M S), F A+37 \cdot 5 g M S, F A+$ $75 \mathrm{~g} M S$ and $F A+15 \circ g M S$ diets.

(Mean logarithms with their standard errors and mean values (in parentheses) for groups of six rats; experimental period of $17 \mathrm{~d}$ )

\begin{tabular}{|c|c|c|c|c|c|c|}
\hline \multirow[b]{2}{*}{ Diet $\ldots$} & \multirow[b]{2}{*}{ FA } & & & & & \multirow[b]{2}{*}{ SE } \\
\hline & & $18 \cdot 7$ & $37 \cdot 5$ & 75 & 150 & \\
\hline Weight increase* & $\begin{array}{l}x \cdot .866^{a} \\
(18)\end{array}$ & $\begin{array}{l}I \cdot 6617^{b} \\
(47)\end{array}$ & $\begin{array}{c}1 \cdot 6326^{b} \\
(40)\end{array}$ & $\begin{array}{c}1 \cdot 6878^{b} \\
(49)\end{array}$ & $\begin{array}{l}\mathrm{I} \cdot 7295^{b} \\
(54)\end{array}$ & 0.0859 \\
\hline Food consumed $(\mathrm{g})$ & $\begin{array}{l}\mathrm{I} \cdot 95 \circ 6^{a} \\
(92)\end{array}$ & $\begin{array}{l}2 \cdot 0933^{b c} \\
(125)\end{array}$ & $\begin{array}{l}2 \cdot 0788^{b} \\
(120)\end{array}$ & $\begin{array}{l}2 \cdot 1081^{b c} \\
(129)\end{array}$ & $\begin{array}{l}2 \cdot 1614^{c} \\
(150)\end{array}$ & 0.0231 \\
\hline Plasma glucose $(\mathrm{g} / \mathrm{l})$ & $\begin{array}{r}0.0504^{a} \\
(I \cdot 14)\end{array}$ & $\begin{array}{c}0.0586^{a} \\
(I \cdot I 6)\end{array}$ & $\begin{array}{c}0.1237^{a b} \\
(I \cdot 4 I)\end{array}$ & $\begin{array}{c}0.1912^{b} \\
\left(1 \cdot 5^{6}\right)\end{array}$ & $\begin{array}{l}0.1990^{b} \\
(1.60)\end{array}$ & 0.0405 \\
\hline Plasma ketones $(\mathrm{mg} / \mathrm{l})$ & $\begin{array}{c}2.6712^{c} \\
(533)\end{array}$ & $\begin{array}{c}2 \cdot 3389^{b} \\
(224)\end{array}$ & $\begin{array}{c}2 \cdot 2495^{b} \\
(18 \mathrm{I})\end{array}$ & $\begin{array}{c}2 \cdot 0293^{a} \\
(133)\end{array}$ & $\begin{array}{l}I \cdot 9216^{a} \\
(87)\end{array}$ & 0.0623 \\
\hline Liver glycogen $(\mathrm{mg} / \mathrm{g})$ & $\begin{array}{c}0.1953^{a} \\
(15.7)\end{array}$ & $\begin{array}{l}0.2341^{a b} \\
(17.2)\end{array}$ & $\begin{array}{c}0.285 I^{b} \\
(19.5)\end{array}$ & $\begin{array}{c}0.4337^{c} \\
(27 \cdot 3)\end{array}$ & $\begin{array}{c}0.5011^{d} \\
(31 \cdot 8)\end{array}$ & 0.0212 \\
\hline $\begin{array}{l}\text { G-6-Pase ( } \mu \text { mol phosphate } \\
\text { released/g per min) }\end{array}$ & $\begin{array}{l}\mathrm{I} \cdot 2730^{\circ} \\
(19 \cdot 18)\end{array}$ & $\begin{array}{r}I \cdot 233^{b c} \\
(17 \cdot 28)\end{array}$ & $\begin{array}{l}\mathrm{I} \cdot 1352^{a} \\
(14 \cdot 24)\end{array}$ & $\begin{array}{r}\mathrm{I} \cdot 1480^{a b} \\
(13 \cdot 77)\end{array}$ & $\begin{array}{l}\mathrm{I} \cdot 0956^{a} \\
(\mathrm{I} 2 \cdot 6 \mathrm{I})\end{array}$ & 0.0309 \\
\hline $\begin{array}{l}\text { GK }(\mu \mathrm{mol} \text { NADPH } \\
\text { produced/g per min) }\end{array}$ & $\begin{array}{r}-0.3771^{a} \\
(0.45)\end{array}$ & $\begin{array}{c}-0.3332^{a} \\
(0.51)\end{array}$ & $\begin{array}{r}-0.2768^{a} \\
(0.55)\end{array}$ & $\begin{array}{r}-0.0116^{b} \\
(1 \cdot 00)\end{array}$ & $\begin{array}{c}-0.0461^{b} \\
(0.92)\end{array}$ & 0.0625 \\
\hline
\end{tabular}

abc Means which have the same superscript are not significantly different at the $P=0.05$ level.

* Mean initial weight, roo g.

cantly higher than that of animals given the FA diet, but was not significantly different from that associated with the higher levels of supplementation tested. This same amount of MS decreased significantly the concentration of ketone bodies in the plasma. Larger inclusions of MS further decreased the concentration of ketone bodies in the plasma. Only with the addition of $75 \mathrm{~g} \mathrm{MS} / \mathrm{kg} \mathrm{FA}$ diet did the concentration of glucose in plasma become similar to levels obtained with diets containing $15 \circ \mathrm{g}$ MS/kg and presumably the CHO diets. The activities of G-6-Pase and GK followed a pattern similar to that outlined in Table 2 except that the activities tended to plateau at about $75 \mathrm{~g} \mathrm{MS} / \mathrm{kg}$ diet.

Table 4 shows the results of the study in which the effects of the fasting of rats given the FA diet daily from 08.30 to 20.30 hours were investigated. Results obtained for rats given the $\mathrm{FA}$ and $\mathrm{CHO}$ diets ad lib. are also shown. The results show that, regardless of the type of diet, rats ate the same amount whether they were fed ad lib. or from 08.30 to 20.30 hours daily. The $08.30-20.30$ hours daily feeding did not influence the weight gain of rats fed on the CHO diet. This type of feeding, however, increased the weight gain of rats given the FA diet. An increase was observed in the concentration of glucose in the plasma of rats given the FA diet from 08.30 to 20.30 daily. At the same time, this type of feeding produced a significant decrease in the concentration of glycogen in the liver of rats receiving the FA diet, regardless of the 
Table 4. Mean logarithm and mean values for weight increase, food consumption, concentrations of glucose and total ketone bodies in plasma and concentration of liver glycogen of rats given the fatty acid $(F A)$ and the carbohydrate $(\mathrm{CHO})$ diets

(Mean logarithms with their standard errors and mean values (in parentheses) for groups of six rats eating $a d$ lib., groups of twelve rats given food for only $12 \mathrm{~h}$ daily (fed), and groups of twelve rats maintained on the latter regimen but fasted before killing (fasted); experimental period of $19 \mathrm{~d}$ )

\begin{tabular}{|c|c|c|c|c|c|c|}
\hline \multirow[t]{2}{*}{ Diet ... } & \multicolumn{3}{|c|}{ FA } & \multicolumn{3}{|c|}{$\mathrm{CHO}$} \\
\hline & Fed & Fasted & Ad lib. & Fed & Fasted & Ad lib. \\
\hline Weight gain* (g) & $\begin{array}{l}1 \cdot 5458^{a} \\
(40) \\
\pm 0.0478\end{array}$ & & $\begin{aligned} & \mathbf{I} \cdot 2009^{b} \\
&(25) \\
& \pm 0.1870\end{aligned}$ & $\begin{array}{l}1 \cdot 9726^{c} \\
(95) \\
\pm 0.0133\end{array}$ & & $\begin{array}{l}\text { I. } 9806^{\circ} \\
(99) \\
\pm 0.0272\end{array}$ \\
\hline Food consumed $(\mathrm{g})$ & $\begin{array}{c}2 \cdot 3276^{a} \\
(218) \\
\pm 0.0283\end{array}$ & & $\begin{aligned} & 2.3310^{a} \\
& (219) \\
\pm & 0.0352\end{aligned}$ & $\begin{array}{c}2 \cdot 4805^{b} \\
(303) \\
+0.0082\end{array}$ & & $\begin{array}{c}2.4797^{b} \\
(304) \\
\pm 0.0204\end{array}$ \\
\hline $\begin{array}{l}\text { Plasma glucose } \\
(\mathrm{g} / \mathrm{l})\end{array}$ & $\begin{array}{c}0.1005^{b c} \\
(1 \cdot 3 \mathrm{I}) \\
\pm 0.0378\end{array}$ & $\begin{array}{l}-0.0020^{b} \\
\quad(1.03) \\
\pm 0.0369\end{array}$ & $\begin{array}{c}-0.1623^{a} \\
(0.70) \\
\pm 0.0379\end{array}$ & $\begin{array}{c}0.2312^{d} \\
(1.72) \\
\pm 0.0191\end{array}$ & $\begin{aligned} & 0.1094^{c d} \\
& (\mathrm{x} \cdot 32) \\
\pm & 0.0333\end{aligned}$ & $\begin{aligned} & 0.1595^{c 0} \\
&(1.44) \\
& \pm 0.0107\end{aligned}$ \\
\hline $\begin{array}{l}\text { Plasma ketones } \\
(\mathrm{mg} / \mathrm{l})\end{array}$ & $\begin{array}{l}2.7159^{\text {ed }} \\
\left(53^{8}\right) \\
\pm 0.0327\end{array}$ & $\begin{aligned} & 2.8 \mathrm{I} 43^{d} \\
& (689) \\
\pm & 0.044 \mathrm{I}\end{aligned}$ & $\begin{aligned} & 2 \cdot 7610^{c d} \\
&(608) \\
& \pm 0.0598\end{aligned}$ & $\begin{aligned} & 2.2473^{a b} \\
&(262) \\
& \pm 0.1265\end{aligned}$ & $\begin{array}{l}2 \cdot 4576^{b c} \\
(357) \\
\pm 0.0940\end{array}$ & $\begin{aligned} & I .9032^{a} \\
&(83) \\
& \pm 0.0462\end{aligned}$ \\
\hline $\begin{array}{l}\text { Liver glycogen } \\
(\mathrm{mg} / \mathrm{g})\end{array}$ & $\begin{array}{c}0.9648^{b} \\
(10.2) \\
\pm 0.0595\end{array}$ & $\begin{array}{c}0.0690^{b} \\
(10.0) \\
\pm 0.0479\end{array}$ & $\begin{aligned} & 1.2048^{c} \\
& (17.0) \\
\pm & 0.0613\end{aligned}$ & 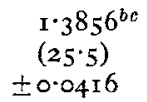 & $\begin{array}{l}0.7108^{a} \\
(6.6) \\
+0.1001\end{array}$ & $\begin{aligned} & I \cdot 8208^{c} \\
& (66.9) \\
\pm & 0.0251\end{aligned}$ \\
\hline
\end{tabular}

abc Means which have the same superscripts are not significantly different at the $P=0.05$ level.

* Mean initial weight, roo g.

fed or fasted states. With respect to ketones and glucose, fasting tended to respectively increase and decrease their concentrations in the plasma regardless of the diet, but these changes were not statistically significant. Further, fasting depressed the concentration of glycogen in the liver of rats given the $\mathrm{CHO}$ diet but did not influence that of rats given the FA diet.

Fig. I shows the weight gain of rats pair-fed on the $\mathrm{CHO}$ diet to the consumption level of the FA diet, as compared with those fed on the CHO diet ad lib. for 8 weeks. After I, 2 and 4 weeks of pair-feeding on the $\mathrm{CHO}$ and FA diets, rats were found to show similar weight increases. Both groups, however, gained significantly less weight than the CHO ad lib.-fed groups. The same trends in weight gain persisted after 8 weeks.

\section{DISCUSSION}

In their attempt to adapt to the FA diet, rats undergo certain metabolic changes that are characteristic of their dependence on fatty acids as the major source of energy and on gluconeogenesis as the sole source of carbohydrate for their tissues. The increase in the concentration of ketones and the decrease in the concentration of glucose in the plasma of rats fed on the FA diet, although statistically significant, were not high enough to produce clinical symptoms of hypoglycaemia and acidotic ketonaemia. It seems that rats were partially successful in adapting to the FA diet. 


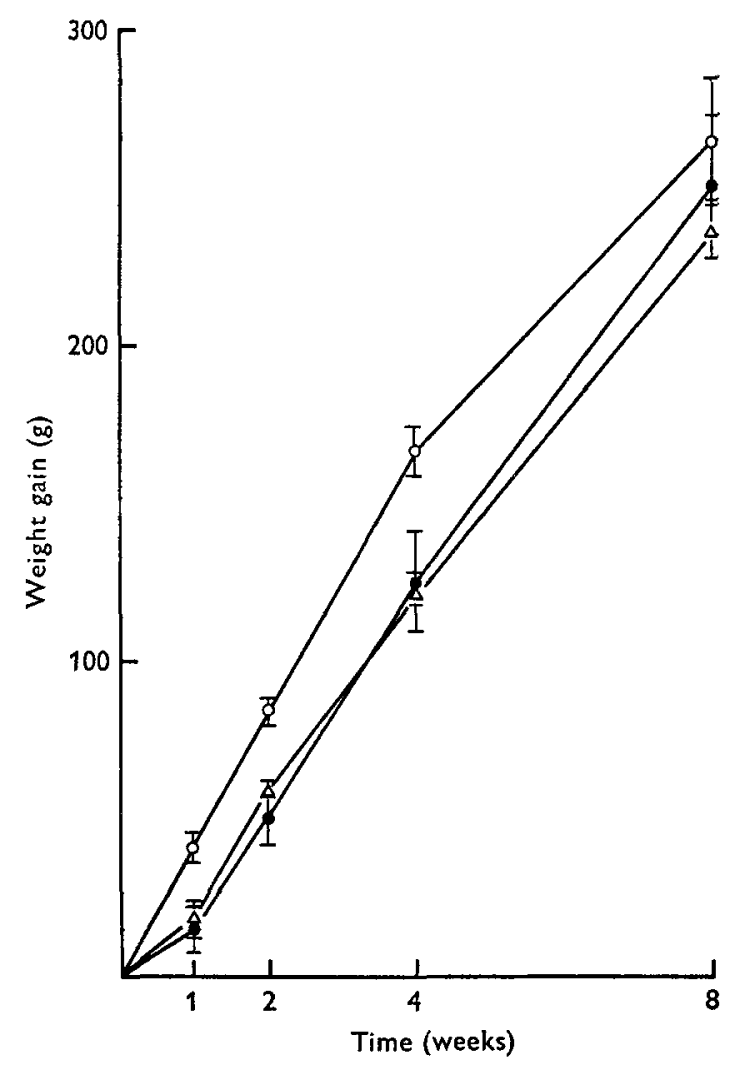

Fig. I. Weight gain of rats after I, 2, 4 and 8 weeks of pair-feeding on the fatty acid (-) and the carbohydrate $(\triangle-\triangle)$ diets and given ad lib. the carbohydrate diet $(\mathrm{O}-\mathrm{O})$. Each point represents the mean value with its standard ertor for five rats.

The increase in the activity of G-6-Pase and the decrease in that of GK in the liver are indicative of the mobilization of the adaptive mechanisms of rats with respect to the synthesis of carbohydrate for tissue needs and the diminished availability of carbohydrate for energy needs.

Further, rats fed on the FA and CHO diets seem to adapt to the stress of fasting similarly. Because eating the FA diet produced metabolic changes characteristic of the fasting state of animals given a normal high-carbohydrate diet (Weber, Singhal \& Srivastava, I965; Freedland, 1967; Lea \& Weber, 1968), it may be theorized that fasting rats fed on the FA diet would produce metabolic alterations different from those in rats fed on the CHO diet. In fact, animals given the FA diet adjusted to fasting, within their own metabolic limits, in ways similar to those given the CHO diet. The plasma glucose concentration decreased with fasting in rats given either the $\mathrm{CHO}$ or the FA diet. There are limited results available (Brambila \& Hill, I967) showing a significant increase in the concentration of glucose in the plasma upon fasting the FA-fed chicken, suggesting a response to fasting in chicks different from that of rats.

Despite the above-mentioned adaptive changes, rats given the FA diet grew at 
a rate that was slower than in those given the CHO diet. This limited growth is related to the reduction in food intake of FA-fed rats since pair-feeding on the FA and CHO diets abolished the difference in weight gain observed when both diets were given ad lib. (Fig. I). The reduction of voluntary food intake of rats fed on the FA diet could be regarded as a form of adaptation to the diet. This reduction can perhaps be explained by the limited ability of the rat to handle the constituents of the diet at the gastrointestinal and metabolic levels. It is known that the rate of stomach emptying of rats fed on the FA diet is slower then in those fed on the same diet but with triglycerides replacing the fatty acids (Akrabawi \& Salji, r973). Presumably the stomach emptying of rats given the FA diet would be also slower than in those given the CHO diet. Thus rats may have reduced their food intake to an amount that could be handled with respect to their ability to esterify the free fatty acids of the FA diet. Further, the capacity of rats for the conversion of dietary amino acids to carbohydrates may have played a controlling role in voluntary food restriction. The FA diet may be regarded as providing an 'imbalanced' amino acid pattern for the purpose of growth since not all of the amino acids are converted to carbohydrates with the same ease. Diets with an imbalanced amino acid pattern are consumed at a slower rate than balanced diets (Harper, I964).

The palatability of the FA diet may have played a role in the reduction of food intake. Both the FA and the FA+r $8.7 \mathrm{~g} \mathrm{MS} / \mathrm{kg}$ diets were quite similar in consistency and bulkiness. However, addition of $18.7 \mathrm{~g}$ MS replacing $8 \mathrm{~g}$ of the $365 \mathrm{~g}$ fatty acids/ $\mathrm{kg}$ FA diet increased the food consumption and weight gain of the supplemented $\mathrm{FA}$ diet to the level of FA+ $150 \mathrm{~g} \mathrm{MS} / \mathrm{kg}$ diet and presumably the CHO diet. Since the addition of $18.7 \mathrm{~g}$ MS is too small to have much effect on the characteristics of the diet, improved palatability as an explanation for the increased intake of the $\mathrm{FA}+\mathrm{r} 8.7 \mathrm{~g} \mathrm{MS} / \mathrm{kg}$ diet seems improbable. A more likely explanation would be that the concentration of $18.7 \mathrm{~g} \mathrm{MS} / \mathrm{kg}$ FA diet was needed to improve the utilization of the FA diet at the gastrointestinal level with respect to fatty acid absorption. Further, the same concentration of MS in the FA diet must have been enough to spare the dietary amino acids to permit their utilization for growth rather than for the synthesis of carbohydrates for tissue needs.

The results obtained in this study indicate that for rats given a $200 \mathrm{~g}$ protein $/ \mathrm{kg}$, carbohydrate-deficient, fatty acid-based diet, an amount of $18.7 \mathrm{~g} \mathrm{MS} / \mathrm{kg}$ diet is needed to prevent the depression in growth and food consumption that results from the dependence on gluconeogenesis for the synthesis of carbohydrate for tissue needs. For abolishing the effects of such a diet on plasma glucose and ketones, about 75 and $300 \mathrm{~g} \mathrm{MS} / \mathrm{kg}$ diet respectively are required.

We are indebted to Miss Sossy Shadarevian for her assistance in the statistical analysis. 


\section{REFERENCES}

Akrabawi, S. \& Hill, F. W. (1970). Fedn Proc. Fedn Am. Socs Exp. Biol. 29, 764.

Akrabawi, S. S. \& Salji, J. P. (1973). Br. F. Nutr. 30, 37.

Allred, J. B. (1969). F. Nutr. 99, го1.

Allred, J. B. \& Roehrig, K. L. (1970). F. Nutr. roo, 61 5.

Brambila, S. \& Hill, F. W. (1966). F. Nutr. 88, 84 .

Brambila, S. \& Hill, F. W. (1967). F. Nutr. 91, 26 r.

DiPietro, D. L., Sharma, C. \& Weinhouse, S. (I962). Biochemistry, Easton $\mathbf{r}, 455$.

Freedland, R. A. (1967). F. Nutr. 9r, 489 .

Goldberg, A. (1971). F. Nutr. ror, 693 .

Harper, A. E. (1964). In Mammalian Protein Metabolism Vol. 2, p. 87 [H. N. Munro and J. B. Allison, editors]. New York and London: Academic Press.

Harper, A. E. (1965). In Methods of Enzymatic Analysis and ed. [H. V. Bergmayer, editor]. New York: Academic Press.

Lea, M. A. \& Weber, G. (1968). F. biol. Chem. 243, rog6.

Lusk, G. (1923). The Elements of the Science of Nutrition $3^{\text {rd }}$ ed. Philadelphia: W. B. Saunders Co.

Renner, R. \& Elcombe, A. M. (I 964). Y. Nutr. 84, 327.

Snedecor, G. W. (1957). Statistical Methods Applied to Experiments in Agriculture and Biology 5 th ed. Ames, Iowa: Iowa State University Press.

Walker, D. G. ( 1963). Biochim. biophys. Acta 77, 209.

Weber, G., Singhal, R. L. \& Srivastava, S. K. (1965). Can. F. Biochem. Physiol. 43, I 549.

Wood, W. A. (1966). Meth. Enzym. 9, 381. 